\title{
LEADERSHIP PRACTICES AMONGST HEADMASTERS OF C ACCREDITED PRIMARY SCHOOLS IN THE REGION OF PASER INDONESIA
}

\author{
Muhammad Rusydi ${ }^{1}$ \\ Faculty Management and Economic, \\ Universiti Pendidikan Sultan Idris (UPSI), Malaysia \\ (Email: muhammadrusydi0769@gmail.com) \\ Zahari Hashim² \\ Faculty Management and Economic, \\ Universiti Pendidikan Sultan Idris (UPSI), Malaysia \\ (Email: zahari@upsi.edu.my)
}

Accepted date: $16-03-2019$

Published date: 17-07-2019

To cite this document: Rusydi, M., \& Hahim, Z. (2019). Leadership Practices Amongst Headmasters of C Accredited Primary Schools in The Region of Paser Indonesia. International Journal of Modern Education, 1(1), 51-60.

DOI: $10.35631 /$ ijmoe. 11005

\begin{abstract}
This research intended to investigate and assess the leadership practices amongst headmasters of $C$ accredited primary schools in the region of Paser, Indonesia. The qualitative research approach was employed in the form of a case study research design. The respondent selection was carried out through the purposive sampling method resulting in the choosing of three primary school headmasters from the region of Paser, Indonesia. The instruments utilized for data collection purposes comprised of interview, observation and document analysis. Research result demonstrated that the three headmasters as school leaders practiced several of the traits proposed in the instructional leadership and leadership strategies theories. The elements that were observed practiced by the headmasters include planning and disseminating school goals, planning teaching management programmes, supervising and assessing teaching programmes, monitoring students' progress, controlling study period, encouraging professional development, maintaining participation in activities, emphasizing academic excellence, preparing incentives for students as well as evaluating the overall school climate. Nevertheless, the research also noted that the headmasters did forgo some of the elements namely evaluating school goals, supervising the curriculum as well as formulating incentives for the teachers. Moreover, said headmasters also faced numerous challenges in practicing leadership qualities. These challenges met by the $C$ accredited primary school headmasters in the Paser region include student, teachers and parents related problems, as well as infrastructure deficiencies. The research thus implied that the leadership characteristics demonstrated by the three participating headmasters could be used as a reference point by other school leaders in Indonesia. Apart from that, the research also urges the ministry of education to take initiative in tackling the aforementioned challenges confronted by headmasters in general.
\end{abstract}




\section{Introduction}

In order to achieve the goal of education in Indonesia aimed at improving the quality of national education, the Indonesian government through the Law Numer 19/2005 on National Education Standards set the standards that must be fulfilled in implementing education, among which is the standard in designing, process standards, competency standards graduates, standard educators and educators, facilities and infrastructure standards, management standards, financing standards, and education assessment standards (Depdiknas, 2005). In addition, the government's efforts to improve the quality of education is through the assessment of the school (Depdiknas, 2012). Based on Law Number 59 on school assessment. Therefore, the Indonesian government has set up a national accreditation body which aims to determine the school's eligibility and quality systematically and thoroughly (Depdiknas, 2012). The level of school accreditation is assessed based on three classifications which is very good (A), good (B), and less (C) assessed based on standard in education implementation (Depdiknas, 2005). It aims to motivate all communities and schoolchildren to implement the standard of education that has been set up (Depdiknas, 2012)

Increasing the desire of the Indonesian government to improve the quality of education in Indonesia, however, based on the Trends in International Mathematics and Science Study (TIMSS) survey of Indonesian students in recent years shows that the achievement of students in mathematics and science learning has dropped. TIMSS (2011) reports that the mastery of Indonesian mathematics and science is ranked 38th with a score of 386 out of 42 countries taking the test (Mullis, Martin, \& Foy, 2011). This result dropped in comparison to TIMSS report in 2007, where Indonesia ranked 36th (Ministry of National Education, 2011). In addition, the Program for International Student Assessment (PISA) report (2015) on programs evaluating the quality of education systems in 72 nations across the nation, found that Indonesia was ranked 62th out of 72 countries. In other words, the quality of education in primary and secondary schools in Indonesia is still below the average level of race compared with other countries in the world (Desi Ariyanti Eka Saputri, 2016). In addition, the National Accreditation Body report (2018) states that there are many schools in the region of Paser with accreditation of C. Suliswiyadi (2017) explaining that many schools still accredited C prove the low quality of education in Indonesia. Therefore, an education system that can improve the quality of education in Indonesia.

In the study of Arong and Ogbadu (2010); Farooq and Sardar (2015) point out that one of the reasons for declining quality of education is due to failing and less effective school management and leadership. In the social structure of the school, school leaders play a role as the link between the policies envisaged by the education ministry and the school community, hence school leaders are important in advancing the quality of education (Pairin, 2010). Hence, Yukl (2006) states that in a school, its leaders and leadership processes are part of contributing factors that can determine the achievement of a desired goal. Furthermore, school leaders can also affect the quality of a school that affects the fall and waking of a society and nation.

\section{Problem Statement}

The education world is constantly changing in parallel with age circulation and demands of the nation's needs. The change is a revolutionary and dynamic process with an emphasis on continuous learning and adaptation. Schools as learning organizations need to continuously improve their performance and build capacity to address changes in the absence of a borderless 
school environment (Matthew, 2017). Therefore, the education system requires a leader who is able to achieve the dream and vision of the country to realize a quality school (Ahmad Riduan, 2013).

Based on the importance of a school leader to the organization he leads, therefore leadership theory has always been of great interest from scholars and researchers (Tonkin, 2016). In summary, the theory of leadership has evolved over a century ago (Zakaria, 2016). Leadership theory includes Behavioral Leadership Theory (Stogdil, 1974; Yukl, 1989), Behavioral Theory (McGregor, 1960; Blake \& Moutun, 1978), and Situational Contiguity Theory (Fiedler, 1976; Hersey \& Blanchard, 1977). These leadership theories have been widely studied and studied. Afterwards, the theories evolved with several leadership styles, namely the instructional leadership style (Hallinger \& Murphy, 1985; Weber, 1996).

With regard to the instructional leadership style, there has been a lot of past studies exploring and studying such leadership styles, including a study conducted by Boyce and Bowers (2018) that school leaders using instructional leadership in leading members are able to improve teacher job satisfaction, teacher commitment and retention teacher. The findings are supported by the study of Brandon, Hollweck, Donlevy and Whalen (2018) which emphasize the advantages of instructional leadership that is to improve the quality of teacher care and teaching practices. In addition, Harris, Jones, Cheah, Devadason, and Adams studies (2017) show that with instructional leadership, principals in Malaysia can reflect their responsibilities in relation to improved teaching practices. In particular, principals actively monitor the quality of teaching and learning in their schools. The previous study also found positive relationships between instructional leadership and educational quality. As the Steele, Johnson, Otten, Eisenmann, and Carver (2015) study finds that skills in instructional leadership are important, therefore the headmasters must upgrade instructional leadership skills to improve the quality of education at a led school. The findings are supported by the study conducted by Mitchell, Kensler and Moran (2015) which show that instructional leadership affects the quality of school education and student achievement.

However there are also school leaders who can not perform their duties as instructional leaders properly. This is because the headmasters as school leaders get the challenge of directing their members (Zakaria, 2016). Subsequently Zakaria (2016) adds to the factors that led to the failure of the school leader as a result of many school principals. In addition there are many other factors that contribute to the failure of school leaders to play their role as instructional leaders, among them the ever-expanding educational process in terms of age and technological developments. Abdullah Sani (2013) also thinks the role and role of the headmasters and principals is increasingly challenging from day to day due to the rapid developments in the education system both inside and outside the country. Next in the study Nurul Azreen (2016) stated that the challenges faced by the headmasters in leading the school were the lack of professional teachers, there was a closed mental mentality among the societies, and the socioeconomic status of the students. Additionally, Andreas (2016) states that lack of infrastructure facilities is a challenge for the headmasters in implementing non-technical leadership, so the headmaster needs to maximize existing infrastructure facilities.

\section{Literature Review}

Several studies on the leadership of the headmaster have been carried out internationally and internationally. The findings show that the leadership of the headmaster plays an important role in determining the success or failure of a school (Vinson, 2018, Matthew, 2017, and Steyn, 2015). Therefore, leaders must act wisely in determining the leadership practices implemented 
(Zakaria, 2016). Many studies have found that headmasters should play their role as instructional leaders in leading their followers. This is because instructional leadership is very effective in improving the quality of education at the school (Steele, Jhonson, Otten, Eisenmann, \& Carver, 2015; Mitchell, Kensler \& Moran, 2015;) Therefore, in this study the researcher tries to explore and learn about instructional leadership in the region of Paser.

Furthermore, to facilitate the study in identifying the headmasters practice in conducting instructional leadership, the researcher adapted the instructional leadership of Hallinger and Murphy (1985) who had built an instructional leadership model based on the Principal Instructional Management Rating Scale (PIMRS) an instrument that was used to recognize surely effective headmasters and effective schools (Hallinger \& Murphy, 1985). The instructional leadership model consists of three dimensions, in which each dimension is accompanied by several elements or sub-dimensions. The three dimensions are, (i) define school goals, (ii) manage teaching programs, and (iii) promote school climate. While in subdimensions there are 11 elements; devising school goals, delivering school goals, supervising and evaluating teaching, coordinating curriculum, monitoring student progress, controlling teaching time, promoting professional development, maintaining incentives, emphasizing academic excellence, providing incentives to students, and providing incentives to teachers (Hallinger \& Murphy, 1985).

In addition, in implementing leadership practices, the headmaster needs to determine the right strategy for achieving the goal (Ahmad Fauzi 2014). Based on the study conducted by Angki Kusuma Dewi (2010); and Arrachmil Azizah, Ahmad Yusuf Sobri \& Imron Arifin (2015) concluded that the exact strategies implemented by the headmasters can improve the quality of teachers and the academic level of the students. David \& Thomas (2017) have built a leadership strategy model which is the stages of the headmaster who led his followers. The leadership strategy is to begin by planning on the practices to be implemented and planning the direction the organization wishes to achieve, then implementing leadership practices, and then conduct assessment and treatment (David \& Thomas, 2017). In this regard, the study attempted to relate two theories, namely instructional leadership theory (Hallinger \& Murphy, 1985) and leadership strategy theory (David \& Thomas, 2017). In the theory of instructional leadership states the elements that must be practiced by the leaders (Hallinger \& Murphy, 1985), while the leadership strategy further explains the steps that must be taken either before or after the practice of leadership (David \& Thomas, 2017). However, both theories equally emphasize on mature planning and defining goals that are intended to be achieved clearly. Figure 1 illustrates the theoretical framework of the study.

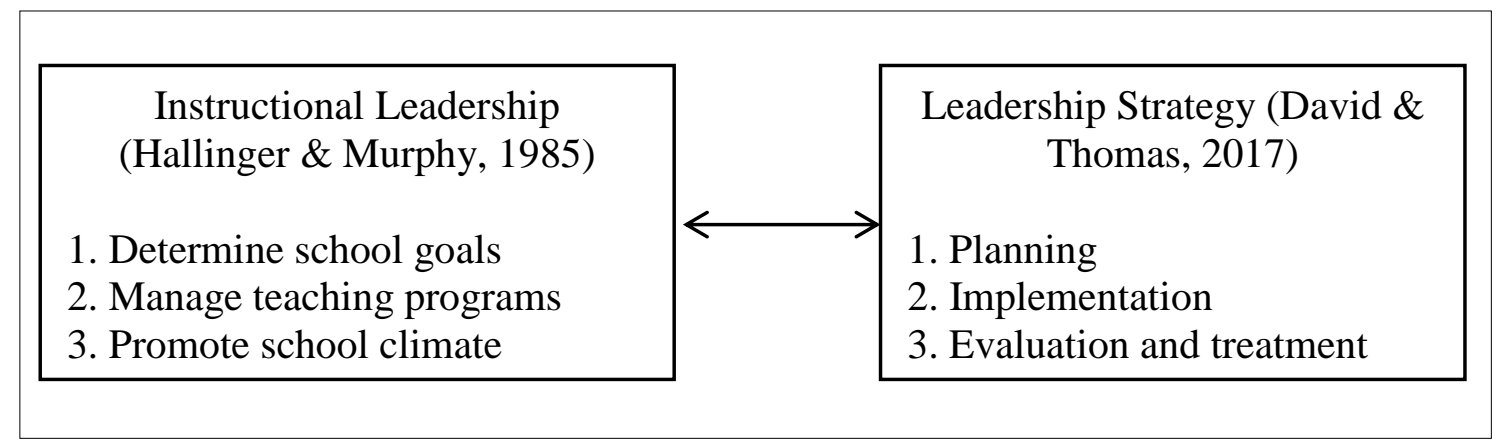

Figure 1. Theoretical Framework of the Study. Adapted from Instructional Leadership Theory (Hallinger \& Murphy, 1985) and Leadership Strategy Theory (David \& Thomas, 2017) 


\section{Conceptual Framework}

According to Smith, Fraser, Chykina, Ikoma, Levitan, Liu, Mahfouz (2017), the conceptual framework is a set of interrelated proposals between the study form, the direction of the study and the theories that have been built or adapted based on previous studies. For the purpose of this study, the researcher has set up a conceptual framework among others namely the quality of education (Sallis, 2002), the practice of leadership of the headmasters in the adaptation of instructional leadership (Hallinger \& Murphy, 1985) and leadership strategy (David \& Thomas, 2017) headmaster challenge (Nurul Khikmah, 2014).

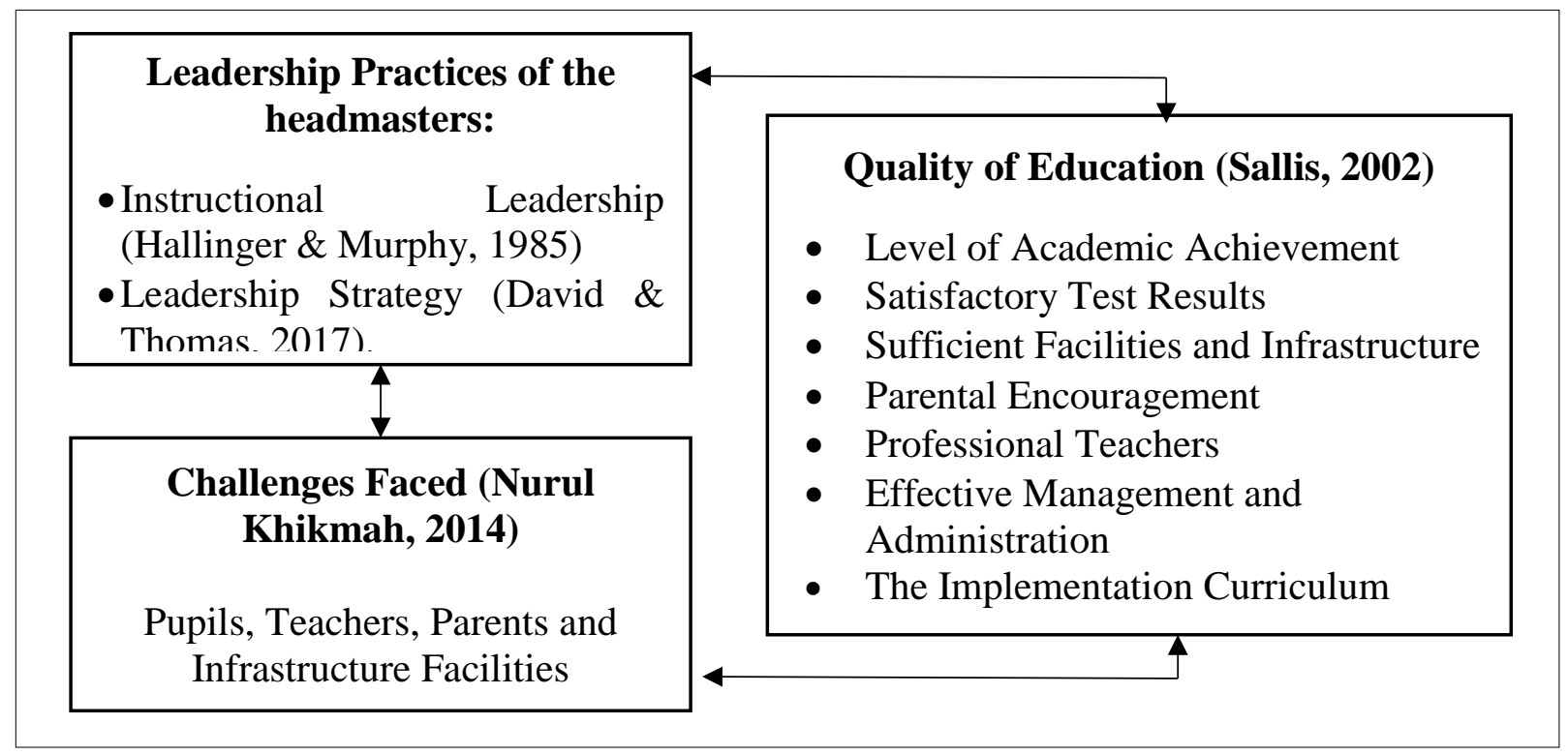

Figure 2. Conceptual Framework.

\section{Research Objective}

In this study, to investigate and assess the leadership practices amongst headmasters of $\mathrm{C}$ accredited primary schools in the region of Paser, Indonesia. The objectives of the study are:

1) Identify the leadership practices amongst headmasters of $\mathrm{C}$ accredited primary school in the region of Paser, Indonesia.

2) Identify the challenges faced by the headmasters in implementing leadership practices at the $\mathrm{C}$ accredited primary school in the region of Paser, Indonesia.

\section{Research Methodology}

To carry out this study, the researcher used qualitative research with the design of case study approach. In this regard, this study explores a phenomenon in the context of the actual situation that occurs in relation to the leadership practices amongst headmasters of $\mathrm{C}$ accredited primary school in the region of Paser, Indonesia.

Furthermore, the sampling method used by the researcher is a purposive sampling based on the characteristics of subjects with expertise, able to represent, ready to participate and easy to contact, can provide mature and accurate data, can provide the most information and description the most accurate to the things you want to study (Chua, 2006). This study was conducted in $\mathrm{C}$ accredited primary schools in the region of Paser, East Kalimantan, Indonesia. Based on data from the region of Paser Education and Culture Office (2017), the primary school 
in the region of Paser is totaling 213 and there are 64 accredited primary schools C. Of the 64 $\mathrm{C}$ accredited primary schools in the region of Paser, then select three become a research site. Thus, the participants of the study were the headmasters of three schools which were purposively determined. The selection of three study participants is sufficient based on the saturation of data from participants (Desi Ariyanti Eka Saputri, 2016).

In this study The instruments utilized for data collection purposes comprised of interview, observation and document analysis. As for the data analysis procedures in this study, researchers analyzed each recorded transcript of the record and also recorded notes on observations and analysis of documents conducted on five stages namely raw data collection, data transcription, data reduction, presentation of data, and drawing conclusions.

\section{Findings}

\section{Leadership Practices}

Two questions were asked to identify the headmaster's leadership practices. The first questionnaire was analyzed to identify the leadership practices amongst headmasters of $\mathrm{C}$ accredited primary school in the region of Paser, Indonesia.. It was found that as a whole the three headmasters as school leaders were trained to practice some of the features and were instructed by instructional leadership theory (Hallinger \& Murphy, 1985) and leadership strategy (David \& Thomas, 2017). For example the study headmasters give priority in determining school goals, managing teaching programs and promoting positive school climate.

It was found that among the elements that were observed practiced by the headmasters include planning and disseminating school goals, planning teaching management programmes, supervising and assessing teaching programmes, monitoring students' progress, controlling study period, encouraging professional development, maintaining participation in activities, emphasizing academic excellence, preparing incentives for students as well as evaluating the overall school climate. Nevertheless, the research also noted that the headmasters did forgo some of the elements namely evaluating school goals, supervising the curriculum as well as formulating incentives for the teachers.

\section{Challenges Faced}

For the second question, it was asked to identify the challenges faced by the headmasters in implementing leadership practices at the $\mathrm{C}$ accredited primary school in the region of Paser, Indonesia.. The findings show These challenges met by the $\mathrm{C}$ accredited primary school headmasters in the Paser region include student, teachers and parents related problems, as well as infrastructure deficiencies.

The problem with which pupils are concerned about the academic performance of students in the examination, often do not come to school, and negative attitudes. Furthermore, the problems associated with the teacher are teachers who do not teach in the field, many teachers who do not understand the application of the new curriculum namely the 2013 curriculum (K13) until the learning process suggested by the ministry of education is not implemented effectively, and still there are teachers who are less committed to teaching. Furthermore, the problems associated with parents are that many parents are less concerned about their child's education. Whereas, in terms of facilities and infrastructure, the findings show that there is a lack of facilities and infrastructure in all three study schools. 


\section{Discussion}

The findings from interviews, observations, and document analysis were analyzed and concluded to answer the first questionnaire to the leadership practices amongst headmasters of $\mathrm{C}$ accredited primary school in the region of Paser, Indonesia. The researcher found that the three headmasters as school leaders were trained to practice some of the features that were instructed by instructional leadership theory (Hallinger and Murphy, 1985) and leadership strategy (David and Thomas, 2017). For example, the headmasters give priority in determining school's goals. This is in line with Danielle and Mohd. Khairuddin (2017) stating that the role of the headmaster in implementing leadership practices is to formulate the goals of the school so that the direction to be achieved is in line with the wishes of all parties involved in education. In addition, the headmasters also manage teaching programs, Jamelaa (2012) explains that the dimension of managing the teaching program effectively can have a positive impact on student achievement based on the studies conducted at secondary schools in Pahang. In managing the teaching programs of the three headmasters also explains the importance of overseeing and assessing the teacher's teaching program. they agreed on the importance of overseeing the teaching program aimed at identifying the problems faced by the teacher, so that the headmasters were easy to assess and correct the problems affecting the learning and teaching process. The findings are consistent with Sergiovanni's (1992) argument which explains in overseeing and assessing the proficiency of the headmasters as a consultant and as a facilitator capable of understanding the needs of teachers and being able to provide an alternative to their own learning. Furthermore, the three headmasters also encourage positive school climate. The findings of the study on the practice reinforce the findings of the Zuraidah study (2009) regarding support leadership practices that encourage teacher learning. Leaders of learning organizations should also include teachers in training and development programs that meet the needs of teachers and provide adequate and current reference materials for teachers (Armstrong \& Foley 2003; Bui \& Baharuch 2010; Jamali \& Sidani 2008; Ortenblad 2004).

The headmasters face various challenges and issues for leadership. The most prominent issues and issues among primary schools in the region of Paser are the concerns of school children. The findings of the study by Abdul Sukor, Nuraini, Mohd Izam Ghazali, and Mohd Hasani Dali (2011) point out that many of the students are less aware of the importance of education. Their learning process only occurs when they come to school, there is no motivation for them to do homework or rehearse the lessons, thus affecting the still low academic performance.

The headmasters also faced problems related to the teacher, with teachers still lacking commitment to teaching. The findings are in line with Ometere's (2013) research findings in the Negros that find headmasters problems sometimes lacking time as many teachers have additional income, such as doing business. As a result of these additional activities, it is hard to expect from a teacher to focus entirely on the responsibilities that teachers can enforce.

Subsequently, based on the studies conducted by the three study schools, it was found that many parents were less concerned with their children's education and thus gave challenges to the practice of headmaster leadership. This is in line with Nurul Khikmah's (2014) opinion illustrating in developing countries as it does in Indonesia, many parents do not understand the importance of their participation in education, especially if their economic situation is low. Their focus is on their basic daily needs. Similarly, studies by Zulkifli, Jamilah, Aminah, and Ismi Arif (2011) find that many parents are less concerned about their children's education, which affects the academic achievement of poor students in Selangor. 
Whereas, in terms of facilities and infrastructure aspects. Based on the findings of the study, there is a lack of facilities and infrastructure in all three study schools. The findings are consistent with the Report from Pro Kaltim (2016) at primary school in Paser showing lack of learning facilities such as old and unfit buildings, no library building, laboratory and other buildings that could give students the opportunity to develop their capabilities beyond classroom. In addition, in Agus Zulrahman's study (2013), states that the quality of education in Paser schools is still low being proven by the lack of facilities in learning. Gulcan (2012) explains that facilities and infrastructure can contribute to the improvement of teachers' teaching activities. Sufean Hussin (2014) also argues that the inefficiency of the interior of the infrastructure is affecting the quality of education. Additionally, Mohd Erfy Ismail, Mohd Ali Samsudin and Ahmad Nurulazam (2014) explained that students equipped with infrastructure facilities at school will influence student achievement, as students are greatly assisted by the availability of available infrastructure.

\section{References}

Abdullah Sani. (2013). Inovasi Pembelajaran. Jakarta: PT. Bumi Aksara.

Abdul Sukor Shaari, Nuraini Yusoff, Mohd Izam Ghazali, \& Mohd Hasani Dali. (2011). Kanak-kanak minority orang asli di Malaysia: Menggapai literasibahasa melayu. Jurnal Pendidikan Bahasa Melayu 59 Malay Languange Journal Education (MyLEJ). Universiti Utara Malaysia. 2(3), 13-21.

Agus Zulrahman. (2013). Peran dinas pendidikan untuk meningkatkan kualitas pendidikan SMAN 1 Tanah Grogot. Jurnal Ilmu Pemerintahan, 1(3), 123-134.

Ahmad Fauzi. (2014). Kepimpinan Instruksional dalam Peningkatan Pengajaran dan Pembelajaran yang Berkesan dalam Kalangan Pensyarah. Universiti Tun Hussein Onn Malaysia. Master Thesis Unpublished.

Ahmad Riduan. (2013). Kajian Kes Strategi Kepimpinan Guru Besar Cemerlang. Universiti Teknologi Malaysia. Master Thesis published.

Angki Kusuma Dewi (2010). Strategi Peningkatan Mutu pendidikan Sekolah Menengah Atas (SMA) Negeri Berprestasi Rendah di DKI Jakarta. Universitas Indonesia. Master Thesis published.

Andreas, S. (2016). Preparing Teachers and Developing School Leaders for the 21 st Century. United States OECD: OECD Publishing.

Armstrong, A. \& Foley, P. (2003). Foundations for a learning organization: organization learning mechanisms. Emerald Insight Journal Learning Organization, 10(2), 74-82.

Arong, F. E \& Ogbadu, M. A. (2010). Major causes of declining quality of education in nigeria from administrative perspective: A case study of dekina local government area. Canadian Social Science, 6(3), 183-198.

Arrachmil Azizah, Ahmad Yusuf Sobri, dan Imron Arifin. (2015). Strategi Kepala Sekolah dalam Meningkatkan Mutu Pendidikan. Universitas Malang Indonesia. Master Thesis Unpublished.

Badan Akreditasi Nasional. (2018). Akreditasi Sekolah 2018, Jakarta: BAN PT

Blake, R. R. \& Mouton, J.S. (1978). The New Managerial Grid, $4^{\text {th }}$ edition. Houston: Gulf Publishing Company.

Boyce, J. \& Bowers, A. J. (2018). Toward an evolving conceptualization of instructional leadership as leadership for learning: meta-narrative review of 109 quantitative studies across 25 years. Journal of Educational Administration, 56 (2), 456-473.

Brandon, J., Hollweck, T., Donlevy, J., \& Whalen, C. (2018). Teacher supervision and evaluation challenges: Canadian perspectives on overall instructional leadership. Teachers and Teaching Theoryand Practice. 24(3), 109-111. 
Chua, Y.P. (2006). Kaedah Penyelidikan. Malaysia: Mc Graw Hill.

Danielle, F.C.Y. \& Mohd. Khairuddin Abdullah. (2017). Analisis perbandingan kepimpinan instruksional pengetua dan kepuasan kerja guru. International Journal of Education, Psychology and Counseling, 2(5), 318-339.

David, J.H. \& Thomas L.W. (2017). Strategic Management and Business Policy, $14^{\text {th }}$ Edition. New Jersey: Pearson Prentice Hall.

Department Pendidikan Nasional. (2005). Undang-undang Nomor 20 Tahun 2003, Tentang Sistem Pendidikan Nasional. Jakarta: Depdiknas.

Department Pendidikan Nasional. (2011). Peraturan Menteri Pendidikan dan Kebudayaan Nomor 3 Tahun 2011, Mutu Pendidikan. Jakarta: Depdiknas.

Department Pendidikan Nasional. (2012). Undang-Undang Nomor 20 Tahun 2003, Tentang Sistem Pendidikan Nasional. Jakarta: Depdiknas.

Desi Ariyanti Eka Saputri. (2016). Penerapan Pendidikan Matematik Realistik Indonesia Di Sekolah Rendah. Universiti Pendidikan Sultan Idris. Master Thesis Unpublished.

Dinas Pendidikan dan Kebudayaan Kabupaten Paser. (2017). Hasil Ujian Nasional Sekolah Dasar Di Kabupaten Paser. Paser: Depdiknas.

Farooq, M.S. \& Sardar, S. (2015). Causes of low-quality performance of public sector schools: An exploration. Journal of Quality and Technology Management, 11(2), 31-52.

Fiedler, F.E. (1976). A theory leadership effectiveness. New York: McGraw Hill.

Gulcan, M.G. (2012). Research on instructional leadership competencies of school principals. Proquest Education Journals. 132(3), 625-635.

Hallinger, P., \& Murphy, J. (1985). Assessing the instructional management behavior of principals. The Elementary School Journal, 86(2), 217-247.

Harris, A., Jones, M., Cheah, K.S.L., Devadason, E., \& Adams, D. (2017). Exploring principals' instructional leadership practices in malaysia: Insights and implications. Journal of Educational Administration, 55(2), 500-512.

Hersey, P. \& Blanchard, K.H. (1977). Management of Organization Behavior: Utilizing Human Resources $3^{\text {rd }}$ Edition. Englewood Cliffs. NJ: Prentice-Hall.

Jamelaa Bibi Abdullah. (2012). Amalan Kepimpinan Instruksional Dalam Kalangan Pengetua Sekolah Menengah di Negeri Pahang: Satu Kajian Kualitatif. Universiti Kebangsaan Malaysia. Doctoral Thesis published.

Matthew, A. (2017). Transformational leadership in education: A review of existing literature. International Social Science Review. 93(1), 1-13.

McGregor, D. (1960). The Human Side of Enterprise. Kuala Lumpur: Mc Graw Hill.

Mitchell, R.M., Kensler, L.A.W., \& Moran, M.T. (2015). Examining the effect of instructional leadership on school academic press and student achievement. Journal of School Leadership, 25(2), 134-145.

Mohd Erfy Ismail, Mohd Ali Samsudin, \& Ahmad Nurulazam. (2014). A multilevel study on trends in Malaysian secondary school students' science attitude: Evidence from TIMSS 2011. International Journal of Asian Social Science. 4(5), 572-584.

Mullis, I. P. S., Martin, M.O., \& Foy, P. (2011). Results in mathematics. Chestnot Hill, MA, USA: TIMSS \& PIRLS International Study Center. Downlod by Http://timssandprils.bc.edu.tims2011.downloads/T11_IR_Mathematics_FullBook.pdf

Nurul Azreen. (2016). Isu dan Cabaran Meningkatkan Kualiti Pendidikan Bertaraf Antara Bangsa. Institut Pendidikan Guru. Paper Project Degree.

Nurul Khikmah. (2014). Kepemimpinan Kepala Madrasah dalam Meningkatkan Mutu Pendidikan MAN Pasuruan. Universiti Pendidikan Negeri Malang. Master Thesis Published.

Ometere Adunola. (2013). Analysis of the Relationship Between Academic Performance and Students Class Size. Nigeria: EgoBooster Books. 
Pairin. (2010). Struktur Sosial di Sekolah. Shautut Tarbiyah 232 (2), 67-90.

Programme for International Student Assessment (PISA). (2015). PISA 2015Results in focus. By: http://www.oecd.org/pisa/keyfindings/pisa-2015-results-overview.pdf

Pro Kaltim. (2016). Puluhan Tahun Masih Ada Gedung Sekolah Tak Layak di Paser. Muat turun dari : http://kaltim.prokal.co/read/news/260794-puluhan-tahun-tak-diperhatikanmasih-ada-gedung-sekolah-tak-layak-di-paser.html.

Sallis, E. (2002). Total Quality Management in Education. $3^{\text {th }}$ Edition. UK: Stylus Publishing Inc.

Sergiovanni, T.J. (1992). Moral Leadership. Sage Journal, 76(5), 121-121.

Smith, W.C., Fraser, P., Chykina, V., Ikoma, S., Levitan, J., Liu,J., \& Mahfouz, J. (2017). Global Citizenship and The Importance of Education in a Globally Integrated World. Globalisation, Societies and Education, 15(5), 648-665.

Steele, M.D., Johnson,K.R., Otten, S., Eisenmann, B.A.H., \& Carver, C.L. (2015). Improving Instructional Leadership Through the Development of Leadership Content Knowledge. Journal of Research on Leadership Education, 10(2), 205-215.

Sufean Hussin. (2014). Cabaran Menyeluruh dalam Pelaksanaan Transformasi Pendidikan untuk Masa Depan Malaysia. National Education Transformation Conference, Universiti Malaya, Malaysia.

Suliswiyadi (2017). Pengaruh Faktor Implementasi Metode Pembelajaran Ranking Satu dalam Keterampilan Menulis Siswa di MI Muhammadiyah Mendut. Jurnal Tarbiyatuna. 8(1). 83-93.

Sugiyono. (2013) Metode Penelitian Pendidikan Pendekatan Kuantitatif, Kualitatif, dan R\&D. Bandung: Alfabeta.

Steyn, G.M. (2015). Creating a Teacher Collaborative Practice in a South African Primary School: The Role of the Principal. Journal of Asian and African Studies, 50(2), 78-90.

Stogdil, R. (1974). Handbook of Leadership: A Survey of Theory and Research. New York: The Free Press.

Tonkin, A. (2016). Leading Schools for Innovation and Success: Five Case Studies of Australian Principals Creating Innovative School Cultures. Doctoral Thesis Published.

Trends in International Mathematics and Sciens Study (TIMSS). (2011). Results in Mathematics. Chestnot Hill, MA, USA: TIMSS \& PIRLS International Study Center. Http://timssandprils.bc.edu.tims2011.downloads/T11_IR_Mathematics_FullBook.pdf

Vinson, S.M. (2018). The Role of the Principal in Effective Professional Learning Communities. University of Oklahoma. Doctoral Thesis Published.

Weber, M. (1996). Essays in Sociology. New York: A Galaxy Book.

Yukl, G.A. (1989). Managerial Leadership: A Review of Theory and Research. Journal of Management, 15(2), 251-289.

Yukl, G.A. (2006). Leadership in Organizations. Pearson: Prentice Hall.

Zakaria Othman (2016). Kepimpinan Intruksional Guru Besar di Sekolah Kurang Murid. Universiti Malaya. Doctoral Thesis Published.

Zulkifli, Jamilah, Aminah, \& Ismi Arif. (2011). Hubungan antara Penglibatan Ibu Bapa Terhadap Pencapaian Akademik Murid Miskin di Negeri Selangor. Journal of Islamic and Arabic Education, 3(2), 31-40.

Zuraidah Abdullah. (2009). Pembentukan Komuniti Pembelajaran Professional: Kajian Terhadap Sekolah Menengah di Malaysia. Jurnal Manajemen Pendidikan, 5(2), 78-96. 